\begin{tabular}{|l|l|l||}
\hline \multicolumn{2}{|c|}{ PublisherInfo } \\
\hline \hline PublisherName & $:$ & BioMed Central \\
\hline \hline PublisherLocation & $:$ & London \\
\hline \hline PublisherImprintName & $:$ & BioMed Central \\
\hline \hline
\end{tabular}

\title{
Does HCMV infection trigger the vascular damage in SSc?
}

\begin{tabular}{|l|l|l||}
\hline \multicolumn{2}{|c|}{ ArticleInfo } \\
\hline \hline ArticleID & $:$ & 132 \\
\hline \hline ArticleDOI & $:$ & $10.1186 /$ ar-2000-66864 \\
\hline \hline ArticleCitationID & $:$ & 66864 \\
\hline \hline ArticleSequenceNumber & $:$ & 89 \\
\hline \hline ArticleCategory & $:$ & Paper Report \\
\hline ArticleFirstPage & $:$ & 1 \\
\hline \hline ArticleLastPage & $:$ & 3 \\
\hline \hline & & RegistrationDate : 2000-11-9 \\
\hline ArticleHistory & $:$ & OnlineDate \\
\hline \hline ArticleCopyright & $:$ & Current Science Ltd2000-11-9 \\
\hline \hline ArticleGrants & $:$ & \\
\hline \hline ArticleContext & $:$ & 130753311 \\
\hline \hline
\end{tabular}


Aff1 Center of Experimental Rheumatology, University Hospital

Zurich, Switzerland

\section{Keywords}

Apoptosis, autoantibodies, endothelial cells, HCMV, SSc

\section{Context}

Systemic sclerosis (SSc) is a connective tissue disease characterized by vascular and immunological abnormalities. The aim of this study was to identify disease-relevant autoantigens.

\section{Significant findings}

Using random peptide library screening, a peptide was identified that was recognized by serum IgG from most SSc patients, but not from healthy controls and only by a minority of serum IgG from rheumatoid arthritis and systemic lupus erythematosus patients. Affinity purified IgG antibodies from the SSc sera against this peptide showed binding activity to different autoantigens such as fibrillarin and cytochrome $\mathrm{C}$ as well as to the human cytomegalovirus (HCMV) late protein UL94. In addition, the cross-reactive epitope of this peptide shared homology with the endothelial cell marker NAG-2. Antibodies against the SSc peptide and the HCMV late protein UL94 both specifically recognized integrin-NAG-2 complexes. When human umbilical vein endothelial cells (HUVECs) were incubated with the affinity-purified antibodies, the antibodies bound to the cell surface, and a dose- and timedependent apoptosis-inducing effect was found that was inhibited by preabsorption with both the SSc and the viral peptide. Moreover, anti-NAG-2 antibodies induced apoptosis of HUVECs.

\section{Comments}

Latent HCMV infections have recently been suggested to be involved in the pathogenesis of SSc (see Additional information). However, the mechanisms by which HCMV may contribute to the progression of the disease, are still hypothetical. In this paper, evidence is provided that HCMV is able to generate self-reactive antibodies in SSc patients. These autoantibodies are able to induce endothelial cell 
apoptosis probably through interaction with the integrin a3?1- and the a6?1-NAG-2 complex. Since endothelial cell apoptosis is thought to be one of the earliest steps in the pathogenesis of SSc, this new pathway may represent an important link between an external trigger (eg cytomegalovirus) and the progressive disease course of SSc. However, it is still not clear, whether immune-alterations follow or precede endothelial changes and whether autoimmune responses in SSc are an epiphenomena. Moreover, future studies have to address why an ubiquitous virus such as HCMV may generate autoimmune responses in some individuals, whereas others show no changes.

\section{Methods}

Random peptide library screening, ELISA, immunoprecipitation, internucleosomal DNA fragmentation measurement

\section{Additional information}

Neidhart M, Kuchen S, Distler O, Bruhlmann P, Michel BA, Gay RE, Gay S: Increased serum levels of antibodies against human cytomegalovirus and prevalence of autoantibodies in systemic sclerosis.

Arthritis Rheum 1999, 42:389-392 (PubMed abstract).

Pandey JP, LeRoy EC: Current comment: human cytomegalovirus and the vasculopathies of autoimmune diseases (especially scleroderma), allograft rejection and coronary restenosis.

Arthritis Rheum 1998, 41:10-15.

\section{References}

1. Lunardi C, Bason C, Navone R, Millo E, Damonte G, Corrocher R, Puccetti A: Systemic sclerosis IgG autoantibodies bind the human cytomegalovirus late protein UL94 and induce apoptosis in human endothelial cells. Nat Med. 2000, 6: 1183-1186.

This PDF file was created after publication. 